\title{
The Effect of Communicative Activities on EFL Learners' Motivation: A Case of Students in the Amazon Region of Ecuador
}

\section{Efecto de actividades comunicativas en la motivación de aprendices del inglés: un caso de estudiantes en la región amazónica del Ecuador}

\author{
César Ochoa ${ }^{1}$ \\ Paola Cabrera ${ }^{2}$ \\ Ana Quiñónez ${ }^{3}$ \\ Luz Castillo 4 \\ Paúl González ${ }^{5}$
}

Citation/ Para citar este artículo: Ochoa, C., Cabrera, P., Quiñónez, A., Castillo, L. E González, P. (2016). The Effect of Communicative Activities on EFL Learners' Motivation: A Case of Students in the Amazon Region of Ecuador. Colomb. Appl. Linguist. J., 18(2), pp. 39-48.

Received: 28-Jan-2016 / Accepted: 24-May-2016

DOI: http://dx.doi.org/10.14483/calj.v18n2.10018

\begin{abstract}
This study sought to shed light on the relationship between communicative activities and their impact on students' motivation to learn English as a Foreign Language (EFL). A total of 180 senior high school learners (86 male and 94 female) and 8 EFL teachers in a town of the Amazon region of Ecuador completed a questionnaire. A sample of these students and all of the teachers participated in a face-to-face interview. Both instruments were applied to obtain data concerned with use of communicative activities in the classroom and their relation with motivation. The data gathered was analyzed using a mixed-method approach, comprising quantitative and qualitative methods. Results showed that students and teachers believe that communicative activities are motivating. Furthermore, students feel highly motivated when participating in communicative activities because these enhance their fluency, pronunciation, and performance in the use of English in a realistic and enjoyable way since students are confident when they help each other during interaction in activities.
\end{abstract}

Keywords: communicative activities, Communicative Language Teaching, EFL learning and teaching, learner's motivation

1 Universidad Técnica Particular de Loja, Ecuador. caochoa@utpl.edu.ec

2 Universidad Técnica Particular de Loja, Ecuador. pacabrera@utpl.edu.ec

3 Universidad Técnica Particular de Loja, Ecuador. alquinones@utpl.edu.ec

4 Universidad Técnica Particular de Loja, Ecuador. Imcastillox@utpl.edu.ec

5 Universidad Técnica Particular de Loja, Ecuador. pfgonzalez@utpl.edu.ec 


\section{Resumen}

El presente estudio pretende determinar la relación entre las actividades comunicativas y su impacto en la motivación de los estudiantes para aprender inglés como lengua extranjera. Para el efecto participaron 180 estudiantes de bachillerato (86 hombres y 94 mujeres), así como 8 docentes de inglés de una localidad de la región amazónica del Ecuador, quienes completaron un cuestionario; además, una muestra de los estudiantes y todos los docentes fueron entrevistados. Tanto la entrevista como la encuesta fueron aplicadas con la finalidad de obtener información acerca de las actividades comunicativas utilizadas en el aula y su relación con la motivación. Los datos obtenidos fueron analizados utilizando una combinación de métodos cuantitativos y cualitativos. Según los resultados, tanto docentes como estudiantes consideran que las actividades comunicativas son motivadoras. Adicionalmente, los estudiantes se muestran altamente motivados cuando participan en actividades comunicativas porque estas desarrollan su fluidez, pronunciación y desenvolvimiento en el uso del inglés en un ambiente real y ameno ya que los estudiantes se sienten más confiados cuando se ayudan entre ellos al interactuar en las actividades.

Palabras clave: actividades comunicativas, enseñanza comunicativa del idioma, enseñanza y aprendizaje de inglés como lengua extranjera, motivación del estudiante

\section{Introduction}

Motivation has been recognized as a crucial factor in language learning because it works as the starting point for learning and supporting the process of foreign language acquisition (Cheng \& Dörnyei, 2007). In this field, several authors around the world have investigated the influence of communicative activities on motivation in EFL learning over the years; however, little consideration has been given to the impact of this issue in EFL learning in Ecuador. Thus, this study adds more light to the body of research on issues about teachers' and students' perceptions regarding motivation at the moment of performing communicative activities in the EFL classroom. It also provides an analysis of the most motivating communicative activities in public schools in order to recommend their use in the EFL classroom. As a result, the teachinglearning process may be improved in the Ecuadorian learning environment.

In terms of communication in the EFL classroom, Communicative Language Teaching (CLT) has been acknowledged by language teachers around the world because of its importance in the improvement of learners' communicative competence (Li $\varepsilon$ Song, 2007). In this context, communicative activities are an essential component in the EFL classroom that engage learners in understanding, manipulating, producing or interacting in the target language (Nunan, 1989). These activities need to be conducted in a pleasant and supportive classroom environment in order to keep students motivated (Dörnyei, 2001a).

Some authors have investigated the connection between communicative activities and motivation in different regions around the world where Spanish has not been the students' mother tongue. Those studies have been focused on different and specific communicative activities (Al Haj, 2011; Cheng \& Dörnyei, 2007; Chou, 2014; Masmaliyeva, 2014; Ngoc \& Iwashita, 2012; Tuan, 2012); nevertheless, few studies on integrating various forms of communicative activities have been conducted. Thus, our study focuses on perceptions of the influence of communicative activities, which were included as items in the form of a questionnaire, on learners' motivation. In this particular case, the participants' mother tongue is Spanish.

\section{Literature Review}

\section{Motivation}

According to Gardner (1985), motivation is perceived as a goal-directed factor since it involves four aspects: a goal, effortful behavior, a desire to reach the goal, and favorable attitudes toward an activity.

Motivation works as the starting point for learning and supporting the process of foreign language 
acquisition. In fact, we can say that if there is lack of motivation, no student will be able to continue with the process of achieving language proficiency; on the other hand, high motivation will be useful for learners to attain proper proficiency in the second language (L2), even if their aptitude or learning conditions are not appropriate (Cheng \& Dörnyei, 2007).

In the field of second language acquisition (SLA), motivation has been acknowledged as a remarkable factor in language learning success. L2 motivation research has evolved over the years through several stages demonstrating gradual integration with developments in motivational psychology, while having a clear focus on aspects of motivation related to language learning (Ushioda \& Dörnyei, 2012).

Harmer (2002) states that motivation is a type of initiative that encourages someone to do things to reach a goal. Furthermore, this is fundamental to succeed in most fields of learning; without such motivation, we will not be able to make the effort to learn. For this reason, it is necessary to understand the role it has when learning a language. The author also distinguishes between extrinsic and intrinsic motivation, which comes from outside and inside the individual respectively.

According to Brown (2001), intrinsic motivation is one of the aspects that helps students succeed in language learning. Of course, there are other factors involved in language learning success, but if learners are provided with opportunities in the classroom to practice the language without depending so much on external rewards for their motivation, they will have a better chance to succeed. When students practice the language for their own personal reasons to become proficient, they will be able to develop their own competence and autonomy to learn the language. In this respect, Harmer (2002) claims that, in general terms, intrinsic motivation comes from within the individual. Thus, students might be motivated by the fact of having an enjoyable learning process or by an impulse to make themselves feel better. Research has acknowledged intrinsic motivation as a decisive factor to stimulate success. Furthermore, in a model of intrinsic motivation proposed by Vallerand (1997), he establishes that intrinsic motivation is related to knowledge, accomplishment, and stimulation.
These three aspects are respectively associated with exploring new ideas and developing knowledge, sensations embraced in attempting to master a task or achieve a goal, and sensations stimulated by performing the task such as aesthetic appreciation or fun and excitement.

Despite the fact that intrinsic motivation is important in the learning process, there are many types of activities that are not necessarily intrinsically motivating (Ryan \& Deci, 2000). This kind of motivation is referred to as extrinsic motivation, the motivation that learners bring into the classroom from outside (Harmer, 2007). It is suggested that "extrinsic motivation is the result of any number of outside factors; for example, the need to pass an exam, the hope of financial reward or the possibility of future travel" (Harmer, 1991, p. 51). Dörnyei (2001b) states that doing an action in order to receive an extrinsic reward or to avoid punishment is related to extrinsic motivation. Ryan and Deci (2000) also define extrinsic motivation as "a construct that pertains whenever an activity is done in order to attain some separable outcome" (p. 60).

\section{Communicative Language Teaching and Communicative Activities}

Richards and Rodgers (1986) define CLT as an approach rather than a method because, at the levels of design and procedure, there is much greater room for individual interpretation and variation than most methods permit. This approach highlights the process of communication, rather than the mastery of language forms, leading the learners' roles to be different than those of traditional second language classrooms.

CLT has been acknowledged by language trainers all over the world. The essence of this method is the improvement of sociolinguistic and linguistic competences. Thus, CLT aims to enhance students' communicative competence so that they can overcome the pitfalls of traditional teaching approaches (Li \& Song, 2007).

In regards to communicative activities, Stern (1992) defines them as activities that involve learners in authentic communication. Furthermore, 
in communicative activities, learners have to activate and integrate their pre-communicative knowledge and abilities in order to use them for the communication of meanings (Littlewood, 1981). In addition, these activities involve a variety of language, no teacher intervention, no material control, and focus on form as well as on meaning. In order to carry out communicative activities, students should have a desire to convey something with a communicative purpose (Harmer, 2007). It is worth mentioning that a language teaching activity can also be a task, but it must meet certain criteria, such as being primarily focused on meaning, having some kind of gap, learners relying on their own resources, and a clearly defined outcome other than the use of language (Ellis, 2009). Thus, "tasks are activities that call for primarily meaning-focused language use" (Ellis, 2003, p. 3).

According to Rao (2002), communicative activities include exercises characterized by student-to-student interaction with little or no monitoring of students' output by the teacher; oral situations characterized by student-teacher interaction with the teacher monitoring and sometimes responding to students' output; content-based teacher responses to students' writing; and the use of songs in the classroom. In addition, Eslami-Rasekh and Valizadeh (2004) give more details of communicative activities such as games, group and pair work, speaking activities, discussions, and listening to others in English.

Previous studies. Although there has been much research in the field of motivation, limited studies have emphasized the impact of classroom communicative activities on EFL learners' motivation.

Cheng and Dörnyei (2007) aimed at evaluating the extent to which a comprehensive list of motivational strategies derived from Western educational contexts was perceived as educationally relevant by Taiwanese teachers of English. They found that the way the teacher presents the learning tasks bears a strong effect on how the students perceive the assigned activity. In fact, the results of this study suggest that communicating an appropriate rationale and strategic advice concerning how to approach a particular activity is endorsed by Taiwanese teachers of English as an essential ingredient of a motivating teaching practice. Furthermore, results demonstrated that certain motivational strategies are culturally dependent. Another interesting finding was that, although communicative and game-like activities have been promoted in Taiwanese EFL settings during the past decade, their spread may be hindered by a test-driven teaching culture, and the perception that learning should be serious, hard work.

Al Haj (2011) conducted research in order to explore and solve a motivational problem in EFL Sudanese secondary students. The author used previous studies, direct observations, and guided interviews in order to obtain valuable information. The results showed that the lack of motivation in EFL classrooms within the study was due to the following factors: teachers and their training, schools, families, and the lack of developing programs which maintain students' interest. Additionally, it was found that a variety of classroom activities play an essential part in motivating students and facilitating the acquisition of EFL. Thus, it is recommended that teachers use debates, games, group work, pair work, interviews, problem-solving, and role-plays in order to stimulate or motivate EFL learners.

In Tuan's (2012) study, key motivational factors influencing students' English learning performance and some effective ways of fostering these factors were analyzed. The aim of the research was to find out whether motivation had any impact on university students' English learning. Results show that $94 \%$ of the participants agreed that motivational activities are necessary. Students like playing games, reading, translation, group or pair work, role-plays, and including television for watching films in English and cassettes for listening.

Ngoc and Iwashita (2012) compared learners' and teachers' attitudes towards four factors related to CLT: the importance of grammar, the quality and quantity of error correction, the use of group and pair work, and the role of teachers in the classroom. The participants were 88 first-year learners and 37 in-service teachers from two universities in Hanoi, Vietnam. The instrument used was a questionnaire based on a 4-point Likert-scale, which was adapted from different surveys used in various studies. The 
data obtained was categorized and statistically analyzed. The results indicate that both groups have favorable attitudes towards CLT, but teachers had more positive attitudes than learners for all the factors, except group and pair work. In fact, students largely welcomed and enjoyed group and pair work and appeared to be relatively enthusiastic about their emerging role as the center of the classroom.

Chou (2014) examined the extent to which activities such as games, songs, and stories helped and motivated 72 Taiwanese EFL primary school pupils (between the ages of 8 and 11) to learn English vocabulary. The instruments used to collect quantitative and qualitative data were self-assessment questionnaires, achievement tests, and interviews. The information gathered was analyzed using statistics software (SPSS). The qualitative data were coded, classified and reported according to their similarities and differences. The results showed that games, songs, and stories had a positive effect on learners' motivation to increase their English vocabulary.

Masmaliyeva (2014) examined the advantages and disadvantages of oral presentation of English language teaching in the classroom. This study based on action research aimed to analyze students' attitude, participation, and language proficiency as a result of using oral presentations instead of the course book in an advanced English speaking class in Turkey. Data was gathered from a sample of 21 undergraduate English language and literature major students, using surveys, video recordings of students' oral presentations, observations, and the attendance of students. Findings revealed that oral presentations increased the students' motivation, confidence, sense of community, ownership over learning, speech fluency, and accuracy.

\section{Research Questions}

Some studies aimed at investigating the connection between communicative activities and motivation have been conducted in other regions where students' mother tongue has been different from Spanish. Furthermore, these studies have been focused on a few communicative activities. Thus, our study attempts to cover a wider range of communicative activities in regards to students' and teachers' perceptions on the influence of those activities on motivation; in this case, the context is Ecuador and the participants' mother tongue is Spanish. Based on this information, we address the following research questions:

1. What are the students' perceptions about their motivation when performing communicative activities in the EFL classroom?

2. What are the teachers' perceptions about their students' motivation when performing communicative activities in the EFL classroom?

3. Which communicative activities are the most motivating in the EFL classroom?

\section{Methodology}

\section{Participants}

The sample for this research was based on statistical information from the Ecuadorian Ministry of Education for the academic year 2015 concerning the number of high schools, geographic location, and number of students enrolled in the second year of public senior high schools.

The participants of the study were 180 senior high school EFL students ( 86 males and 94 females) and $8 \mathrm{EFL}$ teachers in a town of the Amazon region of Ecuador. The population was obtained through random sampling of a total of 335 students enrolled in public high schools. The ages of the students ranged from 15 to 18 years. The students' CEFR (Common European Framework) proficiency levels (Council of Europe, 2001) were A1 and A2, according to the data provided by teachers.

\section{Materials}

1. Questionnaires were administered to both students and teachers. A six-point Likert scale was designed for this study to gather the data about communicative activities and the levels of motivation (non-motivated NM, low motivated LM, moderately motivated MM, highly motivated HM, totally motivated TM, and not-applicable NA). The applied questionnaires consisted of 10 items related to communicative activities.

2. Students' and teachers' interviews were applied. 
Students were asked about the communicative activities that their teachers used in the classroom and about the reasons why they felt motivated to learn the target language. With respect to teachers, they were asked about the communicative activities they used in class and also about the reasons why their students felt motivated to learn English. The interview was comprised of five open-ended questions that inquired about the types of communicative activities that students do in the EFL classroom, the communicative activities that motivate them, the activities that do not motivate students to learn English, whether or not they are motivated to study English, and if the teacher is a factor that influences the students' motivation to learn the target language. The interview for the teachers consisted of five openended questions that included similar themes to the ones in the student's interview, but from the teachers' perspective.

\section{Procedure}

The data for this study were collected in the first term of the 2015 academic year. A mixedmethod approach, which included both quantitative and qualitative data analyses, was used. In the quantitative part, we coded and analyzed the data statistically, whereas, in the qualitative part, we compared and interpreted the opinions of teachers and students and this information was contrasted with the answers given to the interviews. The core assumption of this approach is that the combination of qualitative and quantitative methods provides a more complete understanding of a research problem than either method alone (Creswell, 2014).

The questionnaires were applied to a sample of 180 students and 8 teachers. Furthermore, all of the teachers were interviewed and 40 students of the sample were randomly selected to respond to the interview. In simple random sampling, each individual is selected by chance and each member of the population has an equal probability of being included in the sample. In addition, every possible sample of any size has an equal opportunity of selection (Cochran, 2007).
After the application of instruments, SPSS software was used in the analysis of the data; percentages and mean scores were calculated, presented, and thoroughly analyzed by combining the results obtained to interpret the information.

\section{Results}

This section contains the quantitative analysis of the results obtained from the students' questionnaire. The statistical information was analyzed to determine the effect of communicative activities on students' level of motivation to learn English as a foreign language, which is later compared with teachers' perceptions and the responses from the interviews. The quantitative data is shown in table 1 below.

Table 1 displays the results of answers given by students. In question 1 , there is a tendency of the participants to feel highly motivated when they use English to interact with their classmates $(M=3.78)$.

In the second question, there is a slight tendency of respondents to feel highly motivated $(M=3.57)$ when participating in class discussions (31.67\%). It is important to add that there is a significant percentage $(28.33 \%)$ of students with moderate motivation at the moment of doing this activity.

With respect to question 3 , there is a slight tendency of learners to feel highly motivated when participating in games $(M=3.63)$. However, a significant percentage $(21.67 \%)$ of students does not feel motivated by games.

In the fourth question, students feel highly motivated $(M=4)$ when working in pairs. It is important to notice that a significant amount of participants $(21.11 \%)$ feel moderately motivated.

In question five, students tend to feel highly motivated when performing activities in small groups $(M=4.26)$. Moreover, there is a noteworthy group of learners $(30 \%)$ who are totally motivated with respect to this item. 
The Effect of Communicative Activities on EFL Learners' Motivation

Table 1. Students' Perceptions on the Effect of Communicative Activities on Motivation

\begin{tabular}{|c|c|c|c|c|c|c|c|}
\hline Questionnaire & $\frac{\text { Mean }}{\text { Score }}$ & NM (1) & LM (2) & MM (3) & HM (4) & TM (5) & NA (6) \\
\hline $\begin{array}{l}\text { 1. How do you feel when you use English to interact with your classmates in the } \\
\text { classroom? }\end{array}$ & 3.78 & 1.11 & 14.44 & 17.78 & 45.55 & 14.45 & 6.67 \\
\hline 2. How do you feel when you participate in class discussions? & 3.57 & 5.56 & 13.89 & 28.33 & 31.67 & 11.67 & 8.88 \\
\hline 3. How do you feel when you take part in language games in the classroom? & 3.63 & 21.67 & 7.22 & 10.56 & 26.11 & 16.11 & 18.33 \\
\hline 4. How do you feel when working in pairs in the English class? & 4 & 4.44 & 8.33 & 21.11 & 31.11 & 18.9 & 16.11 \\
\hline 5. How do you feel when working in small groups in the English class? & 4.26 & 5 & 6.67 & 12.78 & 27.22 & 30 & 18.33 \\
\hline 6. How do you feel when taking part in role-plays in the English class? & 3.38 & 13.9 & 8.33 & 35 & 20.55 & 12.78 & 9.44 \\
\hline 7. How do you feel when participating in group oral presentations in the English class? & 3.52 & 6.12 & 19.44 & 19.44 & 35 & 11.67 & 8.33 \\
\hline 8. How do you feel when giving individual oral presentations in the English class? & 3.61 & 5 & 17.22 & 21.11 & 33.89 & 13.89 & 8.89 \\
\hline $\begin{array}{l}\text { 9. How do you feel when you use English to interact with your teacher in the } \\
\text { classroom? }\end{array}$ & 3.58 & 1.11 & 22.23 & 31.11 & 21.11 & 12.22 & 12.22 \\
\hline 10. How do you feel when your teacher corrects your English speaking errors? & 3.89 & 3.89 & 20 & 10.56 & 32.22 & 15.56 & 17.77 \\
\hline
\end{tabular}

Note. $\mathrm{N}=180$.

In the sixth question, the trend is a moderate motivation in regards to participating in activities that involve role playing $(M=3.38)$. In addition, an important quantity of students (20.55\%) feel highly motivated when taking part in role plays.

In the case of oral presentation which corresponds to question 7, the tendency is a high motivation $(M=3.52)$. We want to remark that an important number of learners show low motivation (19.44\%) and moderate motivation (19.44\%) in this activity.

In question nine, most of the participants $(M=3.58)$ tend to feel either moderately or highly motivated in relation to the interaction with their teacher in the classroom. However, a representative percentage of learners (22.23\%) feel low motivation in this regard.

The last question concerning communicative activities is about the way students feel when their teacher corrects their English speaking errors. The tendency here is to feel highly motivated $(M=3.89)$ when being corrected by the instructor.

\section{Discussion of Results}

In this section, the analysis was based on the comparison between teachers' and students' perceptions as a result of the interviews and questionnaires, focusing our attention on the most relevant statistical information and the most outstanding opinions.
Generally speaking, communicative activities, which involve students' interaction with their classmates in the target language, seem to be highly motivating for learners according to students' and teachers' perceptions. This level of motivation, according to the information obtained from the interviews, appears to come from the fact that students feel confident when they help each other during the interaction. The communicative activities involved class discussions, games, pair work, group work, role plays, and group oral presentations.

In order to address the third research question regarding which communicative activities were the most motivating, it was found that both teachers and students believed that games, pair work, smallgroup work, and role plays are the most motivating since they allow learners to use English in a realistic and enjoyable way; furthermore, the aforementioned activities enable students to perform better. In this context, games are considered as an engaging experience for students of all ages and, as Vyas and Patel (2009) suggest, "whenever learners discover a new game with a new set of rules, they get involved in a learning process in order to master the rules and content of the game" (p. 240). Indeed, the teachers who were interviewed claimed that they used games as a means to provide students with a wonderful learning experience by integrating them into their lessons.

Other communicative activities include pair work, group work, and role plays, which have been considered essential exercises that involve a great 
significance for teachers who promote a motivating classroom environment. Group work and pair work foster cooperative learning because students get involved in order to complete the activities. In pairs and groups, students tend to participate more actively, have more chances to be more independent, feel that they can make their own learning decisions, and work without pressure. Indeed, pair work and group work are helpful to motivate quiet students to participate in communicative activities (Harmer, 2007). Regarding role plays, Porter (1987) asserts that it constitutes a communicative technique which develops students' fluency, promotes classroom interaction, and increases motivation.

According to the results from questionnaires and interviews, activities such as class discussions and group oral presentations are less motivating than the previously mentioned activities because not all students have the same EFL proficiency level. This disparity in the proficiency level leads to unequal participation since students with higher performance in the use of English participate more than students with lower proficiency levels. In relation to class discussions, if teachers form heterogeneous groups, introverted students may feel discouraged by the participation of more expressive learners, while confident students might feel that no satisfactory progress is being made (Green, Christopher, \& Lam, 1997).

Despite the results found with respect to group oral presentations, Brooks and Wilson (2015) state that these activities give students an opportunity to practice language skills, teach something to their peers, and lead to higher levels of motivation for the students involved, as they are able to see the results of their hard work when they are successful in their presentation.

In regards to student-teacher interaction in speaking activities, there is a discrepancy in the level of motivation; teachers feel that their students are moderately motivated while students tend to feel highly motivated. This difference comes from the teachers' belief that most students do not understand them when speaking in the target language. Conversely, students think that the teacher is a valuable source that helps them learn the language by giving advice and explanation. An effective relationship established by teachers in the classroom allows their students to have learning opportunities and to be motivated to perform their activities successfully in the academic field as well as in their personal life (Yunus, Osman, E Ishak, 2011).

Another aspect related to communicative activities is oral error correction in speaking. The results show that students feel highly motivated; however, teachers' perception is that students are totally motivated when error correction is provided. This difference can be explained by the fact that teachers, according to the data from the interviews, perceive that their work is highly appreciated by their students and that error correction is beneficial for them. In this respect, James (2013) states that techniques that involve error correction should enhance the students' accuracy in the target language production rather than being threatening to the students. Furthermore, error correction "facilitates the development of communicative skills" because it raises the consciousness of the learner (Ming-chu \& Hung-chun, 2009, p. 103).

The most important goal of a learner is to communicate with people by using the target language, but not all of the students are eager to use English, especially when they are frustrated by failure in L2 use. In this study, when students have to participate in individual communicative activities such as oral presentations, their feeling is that they are highly motivated because these activities enhance their fluency and pronunciation, which is very helpful to master the target language. Meanwhile, the teachers' belief is that their students feel low motivation due to the fact that they are afraid of making mistakes when speaking English in public.

\section{Conclusions}

The findings of this study demonstrate that students and teachers believe that communicative activities, in general terms, are motivating. Students feel confident when they help each other during the interaction in activities such as class discussions, games, pair work, group work, role plays, and group oral presentations. 
Activities such as games, pair work, smallgroup work, and role plays were ranked highly by both students and teachers as the most motivating communicative activities in the EFL classroom. They consider that these types of activities enhance the use of English to perform in a realistic and enjoyable way.

There were minor differences in perceptions between students and teachers when dealing with interaction in oral production. On one hand, teachers think that their students are moderately motivated because they have difficulties understanding their teachers' speech in the target language. On the other hand, students themselves think they feel highly motivated; this might be explained by the fact that students perceive their teachers as a source for providing advice and explanation.

Furthermore, there were also slight discrepancies in perceptions related to communicative activities in oral correction. While students feel highly motivated, teachers believe that their students feel totally motivated at the moment of giving them error feedback. The cause of this difference may be that teachers' error correction is usually seen by students as a key factor for improving their oral production.

\section{Recommendations}

Teachers should always maintain an enjoyable classroom environment to motivate students to learn the target language and allow students to understand the purposes of communicative activities.

Teachers ought to increase the frequency of activities such as games and role-plays since they promote language practice opportunities, learners' independence and create a positive, friendly and affective climate in the classroom. Games can also be used to improve grammar activities which are considered as boring by students.

When students work on communicative activities, teachers should continue providing appropriate feedback and error correction since these are highly motivating for learners. In addition, teachers should keep in mind that interrupting the flow of oral production might mean a step back to the study of the language form or meaning.

In communicative activities, teachers need to be careful when designing and performing the exercises, considering equal opportunities for participation and interaction in order to achieve effective results.

\section{Acknowledgments}

The authors want to take this opportunity to acknowledge Universidad Técnica Particular de Loja authorities for supporting our research. Likewise, the collaboration of the principals, teachers, and students of the participating institutions is immensely valuable.

\section{References}

Al Haj, A. (2011). Enhancing motivation in the EFL classrooms is the solution: A case study of secondary schools of the Gezira state, Sudan. Journal of Language Teaching and Research, 2(3), 524-529. doi:10.4304/jltr.2.3.524-529.

Brooks, G., \& Wilson, J. (2015). Using oral presentations to improve students' English language skills. Kwansei Gakuin University Humanities Review, 19, 199-212. Retrieved from: http://kgur.kwansei.ac.jp/ dspace/bitstream/10236/13201/1/19-14.pdf

Brown, H. (2001). Teaching by principles: An interactive approach to language pedagogy. New York: Longman Pearson Education.

Cheng, H., \& Dörnyei, Z. (2007). The use of motivational strategies in language instruction: The case of EFL teaching in Taiwan. International Journal of Innovation in Language Learning and Teaching, 1(1), 153-174.

Chou, M. (2014). Assessing English vocabulary and enhancing young English as a foreign language (EFL) learners' motivation through games, songs, and stories. Education 3-13, 42(3), 284-297. doi: $10.1080 / 03004279.2012 .680899$

Cochran, W. (2007). Sampling techniques. New York: John Wiley \& Sons.

Council of Europe. (2001). Common European framework of reference for languages: Learning, teaching, assessment. Cambridge: Cambridge University Press. 
Creswell, J. (2014). Research design: Qualitative, quantitative, and mixed methods approaches. Thousand Oaks: Sage Publications.

Dörnyei, Z. (2001a). Motivational strategies in the language classroom. Cambridge, England: Cambridge University Press.

Dörnyei, Z. (2001b). Teaching and researching motivation. Harlow, England, United Kingdom: Longman.

Ellis, R. (2003). Task-based language learning and teaching. New York: Oxford University Press.

Ellis, R. (2009). Task-based language teaching: Sorting out the misunderstandings. International Journal of Applied Linguistics, 19(3), 221-246.

Eslami-Rasekh, Z., \& Valizadeh, K. (2004). Classroom activities viewed from different perspectives: Learners' voice vs. teachers' voice. TESL EJ, 8(3), 1-13.

Gardner, R. (1985). Social psychology and second language learning: The role of attitudes and motivation. London: Edward Arnold.

Green, C., Christopher, E., \& Lam, J. (1997). Developing discussion skills in the ESL classroom. ELT Journal, 51(2), 135-143.

Harmer, J. (1991). The practice of English language teaching-Motivational differences. London: Longman.

Harmer, J. (2002). The practice of English language teaching: Describing learners. Harlow: Pearson Education.

Harmer, J. (2007). How to teach English. Harlow: Pearson Education Limited.

James, C. (2013). Errors in language learning and use: Exploring error analysis. New York: Routledge.

Li, Z., \& Song, M. (2007). The relationship between traditional English grammar teaching and communicative language teaching. US-China Education Review, 4(1), 62-65.

Littlewood, W. (1981). Communicative language teaching: An introduction. Cambridge: Cambridge University Press.

Masmaliyeva, L. (2014). Using affective effectively: Oral presentations in EFL classroom. Dil Ve Edebiyat Egitimi Dergisi, 2(10), 145-154.
Ming-chu, L., \& Hung-chun, W. (2009). Perception differences of EFL teachers and students in grammar instruction and error correction. English Teaching $\mathcal{E}$ Learning, 33 (1), 101-146.

Ngoc, K., E Iwashita, N. (2012). A comparison of learners' and teachers' attitudes toward communicative language teaching at two universities in Vietnam. University of Sydney Papers in TESOL, 7, 25-49.

Nunan, D. (1989). Designing tasks for the communicative classroom. Cambridge: Cambridge University Press.

Porter, L. (1987). Role play. Oxford: Oxford University Press.

Rao, Z. (2002). Chinese students' perceptions of communicative and non-communicative activities in EFL classroom. System, 30(1), 85-105. doi:10.1016/ S0346-251X(01)00050-1

Richards, J. C., \& Rodgers, T. (1986). Approaches and methods in language teaching. Cambridge: Cambridge University Press.

Ryan, R., \& Deci, E. (2000). Intrinsic and extrinsic motivations: Classic definitions and new directions. Contemporary Educational Psychology, 25(1), 5467. doi:10.1006/ceps.1999.1020

Stern, H. H. (1992). Issues and options in language teaching. Oxford: OUP.

Tuan, L. (2012). An empirical research into EFL learners' motivation. Theory and Practice in Language Studies, 2(3), 430-439. doi:10.4304/tpls.2.3.430439

Ushioda, E., \& Dörnyei, Z. (2012). Motivation. In S. Gass $\mathcal{E}$ A. Mackey (Eds.), The Routledge handbook of second language acquisition (pp. 396-409). New York: Routledge.

Vallerand, R. (1997). Toward a hierarchical model of intrinsic and extrinsic motivation. In M. P. Zanna (Ed.), Advances in experimental social psychology (pp. 271-360). San Diego: Academic Press.

Vyas, M., \& Patel, Y. (2009). Teaching English as a second language: A new pedagogy for a new century. New Delhi: PHI Learning Pvt. Ltd.

Yunus, M., Osman, W., \& Ishak, N. (2011). Teacherstudent relationship factor affecting motivation and academic achievement in ESL classroom. ProcediaSocial and Behavioral Sciences, 15, 2637-2641. 